\title{
RESPON PERTUMBUHAN BIBIT TANAMAN SALAK PONDOH (Salacca edulis Reinw) AKIBAT BERBAGAI DOSIS PUPUK KANDANG AYAM
}

\author{
Josina I.B.Hutubessy, Konstantinus Febryanto Beda \\ Program Sudi Agroteknologi Fakultas Pertanian Universitas Flores \\ irenehutubessy91@yahoo.co.id
}

\begin{abstract}
Response of growth of Salacca edulis reinw due to various dosage of chicken fertilizer. This study aims to know to employ organic fertilizer stall chicken at variable growth seed malacca with dose optimum organic fertilizer stall chicken the supply growth seed malacca the optimum. his study used a randomized block design $(\mathrm{RAK})$ with treatment the at use $\mathrm{PO}_{0}=0$ gram polybag ${ }^{-1}, \mathrm{PO}_{1}=50$ gram polybag ${ }^{-1} \mathrm{PO}_{2}$ $=100$ gram polybag $^{-1}, \mathrm{PO}_{3}=150$ gram polybag $^{-1}, \mathrm{PO}_{4}=200$ gram polybag ${ }^{-1}$. Variable growth observed in this study is plant height, wide of the leaf, the number of leaves, length of root, fresh of weight, and dry of weight. Data were statistically analyzed, and followed by test BNT standard $5 \%$. Studies indicate that present organic fertilizer stall chicken about malacca gives very real about all variable monitoring plant height $14,15 \%$, wide of leaf $36,46 \%$, the number of leaf $30,43 \%$, long of root $21,00 \%$, fresh of weight $47,42 \%$, and dry of weight $42,44 \%$. Dose optimum organic fertilizer stall chicken the supply growth seed malacca the optimum is 200 gram polybag $^{-1}$.
\end{abstract}

Keywords : dose, growth seed salacca zalacca and organic fertilizer

\section{PENDAHULUAN}

Salak pondoh (Salacca edulis Reinw) merupakan salah satu jenis salak yang memiliki keunggulan rasa buah manis meskipun belum matang, memiliki kandungan air yang cukup tinggi yakni $78 \%$, berbuah sepanjang tahun, masa simpan buah lebih dari 20 hari, bila dimakan dalam jumlah banyak tidak menimbulkan efek sebah (tidak enak diperut), dan harga jual relatif lebih tinggi. Tanaman salak pondoh merupakan tanaman yang memiliki kandungan nutrisi komplit seperti: karbohidrat, protein, asam amino, mineral dan vitamin (Widuri et al, 2013; Purnomo, 2001)

Salak merupakan tanaman tahunan, oleh sebab itu kesalahan dalam perlakuan benih dan proses pembibitan akan berakibat buruk dalam pengusahaannya, walaupun diberi perlakuan kultur teknis seperti pemupukan, penyiraman, penyiaangan dan pengaturan jarak tanam yang baik. Sampai saat ini pengembangan teknik pembibibitan salak pondoh masih sangat terbatas sehingga kualitas bibit rendah dan tidak berkembang dengan baik. 
Selain penggunaan benih unggul, memperbaiki ketersediaan unsur hara pemilihan media tanam yang sifatnya dalam tanah untuk kesuburan tanaman ringan, remah dan subur merupakan salah satu upaya agar pelaksanaan pembibitan tanaman salak pondoh dapat mencapai tingkat keberhasilan tinggi (Anarsis, 2006; Sutoyo et al, 2010).

Pertumbuhan benih yang baik merupakan faktor utama dalam memperoleh tanaman yang baik di lapangan, maka memerlukan pemupukan yang tepat dalam penanganan dan pemeliharaan bibit tanaman yang tepat. Pemupukan benih bertujuan menjamin kecukupan dan keseimbangan hara selama proses pembibitan salak pondoh serta menghasilkan produksi tandan buah segar yang optimal sehingga diperoleh produksi yang baik. Sejauh ini para petani kurang memperhatikan tindakan pemupukan dipembibitan salak pondoh yang berfungsi sebagai penambah unsur hara didalam tanah untuk dapat meningkatkan pertumbuhan, yang nantinya akan berdampak terhadap pertumbuhan tanaman salak pondoh selanjutnya (Anarsis, 2006; Ismail F, 2012).

Pemupukan dilakukan sebagai upaya untuk mencukupi kebutuhan tanaman agar tujuan produksi dapat dicapai. Pemberian pupuk dapat yang telah hilang akibat proses penguapan, erosi, pencucian saat hujan dan terangkut pada saat panen. Kekurangan unsur hara $\mathrm{N}, \mathrm{P}, \mathrm{K}, \mathrm{Mg}, \mathrm{S}$ dan $\mathrm{Ca}$ dapat mengakibatkan pengaruh buruk terhadap pertumbuhan tanaman. Karena unsur hara tersebut diperlukan untuk menghasilkan pertumbuhan dan perkembangan tanaman. Faktor yang mempengaruhi pertumbuhan bibit salak pondoh adalah ketersediaan hara bagi tanaman. Unsur hara makro esensial yang dibutuhkan tanaman adalah unsur nitrogen $(\mathrm{N})$ dan fosfor $(\mathrm{P})$, yang dapat ditambahkan ke dalam tanah dalam bentuk pupuk (Alinajati dan Mirshekari, 2011). Peningkatan unsur hara pada masa pembibitan dapat diatasi dengan pemberian pupuk organik. Secara fisik bahan organik berperan dalam merangsang granulasi, menurunkan flastisitas dan kohesi, memperbaiki struktur tanah, meningkatkan daya tahan tanah dalam menahan air sehingga drainase tidak berlebihan, kelembaban dan temperatur tanah menjadi stabil, selain itu dapat meningkatkan jumlah dan aktivitas mikroorganisme tanah. Penggunaan pupuk organik dapat berperan juga dalam menanggulangi 
pencemaran lingkungan serta adalah unsur N (5\%), P (0,81\%); K (0,4 meningkatkan kualitas lahan yang \%) dan air (55 \%) (Sutedjo, 2010; berkelanjutan (Hanafiah, 2004; Sutedjo, Sutono, 2002). Menurut Subroto (2009) 2010).

Pupuk kandang adalah salah satu contoh pupuk organik yang berasal dari kotoran ternak baik yang padat maupun yang cair yang kualitasnya sangat tergantung pada jenis ternak, pakan ternak dan cara penampungan pupuk kandang. Pupuk kandang dapat membuat tanah menjadi subur, gembur dan mudah diolah yang tidak dapat digantikan oleh pupuk buatan. Kandungan unsur hara dalam kotoran ternak yang penting untuk tanaman antara lain unsur nitrogen $(\mathrm{N})$, fosfor (P) dan kalium (K). Ketiga jenis unsur hara ini sangat penting diberikan karena masing-masing memiliki fungsi penting bagi pertumbuhan tanaman. Salah satunya adalah pupuk kandang ayam (Widowati et al, 2005; Mayadewi, 2007).

Pupuk kandang ayam merupakan pupuk organik yang memiliki keunggulan antara lain, menyuburkan tanaman secara alami karena mengandung beberapa jenis unsur hara baik mikro maupun makro, memperbaiki struktur tanah dan meningkatkan jasat renik tanah. Kandungan unsur hara yang terkandung pada pupuk kandang ayam dan Raihan (2000), bahwa pemberian pupuk kandang ayam dapat memperbaiki struktur tanah serta dapat memperkuat akar tanaman, sebagai pemasok hara tanah dan meningkatkan retensi air

Hasil penelitian Sondang et al (2012) menunjukkan bahwa pemberian pupuk organik kandang ayam 100 gram/polibag ukuran $35 \mathrm{~cm} \mathrm{x} 40 \mathrm{~cm}$, memberikan pertumbuhan terbaik pada bibit tanaman kelapa sawit, diantaranya tinggi bibit tanaman (30,55\%), jumlah daun $(5,22 \%)$, diameter batang $(2,10 \%)$, volume akar $(44,66 \%)$, dan bobot basah (140.46\%) juga meningkat. Sehubungan dengan uraian di atas maka penelitian pengaruh Pupuk Organik Kandang Ayam Terhadap Pertumbuhan Bibit Tanaman Salak Pondoh (Salacca edulis Reinw) perlu untuk dilakukan.

\section{METODE PENELITIAN}

\section{Tempat dan Waktu Penelitian}

\begin{tabular}{lcr}
\multicolumn{1}{c}{ Penelitian } & dilaksanakan & di kebun \\
percobaan & Fakultas & Pertanian \\
Universitas & Flores, & Kelurahan \\
Lokoboko, & Kecamatan & Ndona, \\
Kabupaten & Ende. Penelitian & dilakukan \\
mulai bulan Mei - Juli 2019. &
\end{tabular}

Bahan dan Alat 
Bahan yang digunakan dalam Lokoboko, Kecamatan Ndona, penelitian ini adalah biji salak pondoh, Kabupaten Ende. Tanah yang akan tanah, pasir, polybag ukuran $20 \mathrm{~cm} \times 25$ digunakan untuk media tanam dalam $\mathrm{cm}$, kotoran ternak ayam dan air bersih.

Alat yang digunakan dalam penelitian adalah parang, karung/terpal, ember, meteran, timbangan analitik, gembor, sekop, cangkul, ayakan, kertas milimeter, hand sprayer, kamera dan alat tulis.

\section{Rancangan Penelitian}

Penelitian ini menggunakan Rancangan Acak Kelompok (RAK) dengan pola faktor tunggal terdiri dari 5 perlakuan yaitu:

$\mathrm{PO}_{0}=0$ garam polibag ${ }^{-1}$ (kontrol) dosis pupuk organik kandang ayam

$$
\mathrm{PO}_{1}=50 \text { gram polibag }{ }^{-1} \text { dosis }
$$

pupuk organik kandang ayam

$$
\mathrm{PO}_{2}=100 \text { gram } \text { polibag }^{-1} \text { dosis }
$$
pupuk organik kandang ayam

$$
\mathrm{PO}_{3}=150 \text { gram } \text { polibag }^{-1} \text { dosis }
$$
pupuk organik kandang ayam

$$
\mathrm{PO}_{4}=200 \text { gram polibag }{ }^{-1} \text { dosis }
$$

$$
\text { pupuk organik kandang ayam }
$$

Setiap perlakuan diulang sebanyak 4 kali sehingga terdapat 20 petak percobaan.

Media tanam yang digunanakan dalam penelitian ini adalah tanah. Tanah yang digunakan diambil dari kebun percobaan Fakultas Pertanian Universitas Flores, Keluharan keadaan kering udara kemudian diayak dengan ayakan $2 \mathrm{~mm}$.

1. Benih salak pondoh dipilih berdasarkan ukuran dan berat yang seragam, berwarna coklat tua, ukuran normal serta berasal dari pohon induk yang berkualitas

2. Menyiapkan tempat persemaian dengan cara, kertas koran direndam dalam air kemudian disobek kecilkecil sebanyak mungkin, kemudian diletakan pada wadah (kerangjang plastik) sebagai alas persemainan dan pastikan wadah persemaian memiliki lubang.

3. Benih salak pondoh dibersikan dari daging buahnya dan dicuci, sehingga tidak ada daging buah yang tersisa pada benih salak pondoh

4. Kemudian setiap benih yang sudah di bersikan dibungkus dengan dengan kertas koran yang sudah direndam dalam air. Diusahakan proses pembungkusan dilakukan sesegera mungkin agar proses perkecambahan dapat tumbuh serentak. Selanjutnya setiap benih salak pondoh yang sudah dibungkus dengan kertas koran tadi 
diletakan kedalam wadah persemain yang sudah disiapkan.

5. Selanjutnya ambil lagi kertas koran yang direndam dalam air lalu disobek kecil-kecil sebanyak mungkin untuk digunakan menutup setiap benih salak pondoh yang sudah dibungkus sampai tertutup kertas koran. Kemudian wadah persemain salak pondoh tadi ditempatkan ditempat teduh dan lembap, misalnya didekat sumur atau dibawah pohon yang pencahayaan sinar mataharinya 50 - 70\% dan agar kelembapannya terjaga, lakukan penyiraman setiap pagi dan sore dengan air bersih.

6. Benih salak pondoh yang sudah berkecambah dihari ke-3 atau ke-4 sudah dapat dipindahkan ke polybag pembibitan.

Tanah yang sudah disiapkan kemudian diberi pupuk organik dengan cara dicampur, yakni:

$\mathrm{PO} 0=0$ gram polibag-1 pupuk organik kandang ayam (kontrol)+1000 gram tanah

$\mathrm{PO} 1=50$ gram polibag-1 pupuk organik kandang ayam + 950 gram tanah $\mathrm{PO} 2=100$ gram polibag-1 pupuk organik kandang ayam + 900 gram tanah PO3 = 150 gram polibag-1 pupuk organik kandang ayam +850 gram tanah
PO4 = 200 gram polibag-1 pupuk organik kandang ayam +800 gram tanah.

\section{Variabel Pengamatan}

Pengamatan dilakukan secara distruktif dan setiap pengamatan membutuhkan 4 tanaman sampel, pengamatan meliputi:

1. Tinggi Tanaman $(\mathrm{cm})$.

Diukur dari permukaan tanah sampai titik tumbuh tertinggi dengan menggunakan meteran. Pengukuran tanaman dilakukan pada umur 30, 45, 60, 75, dan 90 hari setelah bibit ditanam (hsbd).

2. Jumlah Daun bibit ${ }^{-1}$ (helai).

Penghitungan jumlah helai daun bibit ${ }^{-}$ 1 dilakukan dengan cara menghitung seluruh helai daun yang telah terbuka sempurna pada bibit. Penghitungan di lakukan umur 30, 45, 60, 75, dan 90 hsbd.

3. Luas Daun bibit ${ }^{-1}\left(\mathrm{~cm}^{2}\right)$.

Luas daun dihitung pada saat tanaman berumur 30, 45, 60, 75, dan 90 hsbd yaitu dengan metode gravimetri. Untuk pelaksanaan dengan metode gravimetri adalah sebagai berikut, ambil daun untuk dihitung luas daunnya. Kemudian mengukur luas kertas yang dijadikan sebagai cetakan daun yaitu dengan rumus panjang $\mathrm{x}$ 
lebar sehingga diperoleh nilai luas kertas (LK). Selanjutnya menimbang kertas yang dijadikan sebagai cetakan daun sehingga diperoleh bobot kertas (Wt). Kemudian membuat pola daun yang dijadikan sebagai sampel diatas kertas cetakan yang telah diketahui luas dan bobotnya, setelah itu pola daun kertas yang digunting ditimbang sehingga diperoleh bobot kertas replika daun (Wt). Langkah selanjutnya menghitung luas daun dengan menggunakan rumus :

$L D=\frac{W r x L k}{W t}$

Keterangan:

$$
\begin{aligned}
\mathrm{LD} & =\text { luas daun } \\
\mathrm{Wr} & =\text { berat kertas replika daun } \\
\mathrm{Wt} & =\text { berat total kertas } \\
\mathrm{Lk} & =\text { luas total kertas }
\end{aligned}
$$

\section{Panjang akar}

Pengamatan bibit tanaman dilakukan pada umur 30, 45, 60, 75, dan $90 \mathrm{hsbd}$ menggunakan metode dekstruksi. Dengan cara polibag dari bibit tanaman salak pondoh disobek sala satu sisi, setelah itu media tanah disemprot agar media tanah dapat terpisah dari akar tanaman dan menghindar putusnya akar, kemudian barulah mengukur panjang akar dari bibit tanaman salak pondoh.

5. Berat berangkasan segar total $\tan ^{-1}(\mathrm{~g})$ Berat segar total $\tan ^{-1}$ ditentukan dengan menimbang seluruh bagian tanaman (akar, batang dan daun) dengan timbangan eletrik, yang sebelumnya tanaman telah dibersikan dari kotoran dan sisa-sisa tanah menggunakan air. Pengamatan dilakukan pada umur 30, 45, 60, 75, dan 90 hsbd.

6. Berat kering oven total $\tan ^{-1}(\mathrm{~g})$

Berat kering oven total $\tan ^{-1}$ diperoleh dengan menimbang seluruh brangkasan hasil pengovenan baik akar, batang dan daun. Selanjutnya pengamatan dilakukan pada umur 30, 45, 60, 75, dan 90 hsbd.

Data hasil pengamatan dianalisis dengan menggunakan analisis sidik ragam sesuai dengan rancangan yang digunakan. Apabila perlakuan menunjukkan pengaruh yang nyata atau sangat nyata terhadap variabel yang diamati, maka pengujian dilanjutkan dengan uji nilai beda rata-rata menggunakan uji BNT $5 \%$ (Gomez dan Gomez, 2007).

\section{HASIL DAN PEMBAHASAN}


Berdasarkan hasil analisis statistik daun umur 75 Hst dan 90 Hst, luas daun, pada tabel signifikasi menunjukan panjang akar, berat segar brangkasan, bahwa penggunaan pupuk organik dan berat kering oven. Serta berpengaruh kandang ayam memberikan pengaruh nyata pada jumlah daun umur $30 \mathrm{Hst}, 45$ yang sangat nyata terhadap variabel Hst dan 60 Hst. pertumbuhan tinggi tanaman, jumlah

Tabel. 1 Signifikasi Penggunaan Pupuk Organik Kandang Ayam Pertumbuhan Tanaman Salak Pondoh

\begin{tabular}{|c|c|c|}
\hline $\mathrm{NO}$ & VARIABEL PENGAMATAN & SIGNIFIKANSI \\
\hline 1 & Tinggi Tanaman $30 \mathrm{Hst}$ & $* *$ \\
\hline 2 & Tinggi Tanaman $45 \mathrm{Hst}$ & $* *$ \\
\hline 3 & Tinggi Tanaman $60 \mathrm{Hst}$ & $* *$ \\
\hline 4 & Tinggi Tanaman 75 Hst & $* *$ \\
\hline 5 & Tinggi Tanaman $90 \mathrm{Hst}$ & $* *$ \\
\hline 6 & Jumlah Daun 30 Hst & $*$ \\
\hline 7 & Jumlah Daun 45 Hst & $*$ \\
\hline 8 & Jumlah Daun 60 Hst & $*$ \\
\hline 9 & Jumlah Daun 75 Hst & $* *$ \\
\hline 10 & Jumlah Daun 90 Hst & $* *$ \\
\hline 11 & Luas Daun 30 Hst & $* *$ \\
\hline 12 & Luas Daun 45 Hst & $* *$ \\
\hline 13 & Luas Daun 60 Hst & $* *$ \\
\hline 14 & Luas Daun 75 Hst & $* *$ \\
\hline 15 & Luas Daun 90 Hst & $* *$ \\
\hline 16 & Panjang Akar $30 \mathrm{Hst}$ & $* *$ \\
\hline 17 & Panjang Akar 45 Hst & $* *$ \\
\hline 18 & Panjang Akar $60 \mathrm{Hst}$ & $* *$ \\
\hline 19 & Panjang Akar 75 Hst & $* *$ \\
\hline 20 & Panjang Akar $90 \mathrm{Hst}$ & $* *$ \\
\hline 21 & Berat Brangkasan Segar Total Pertanaman 30 Hst & $* *$ \\
\hline 22 & Berat Brangkasan Segar Total Pertanaman 75 Hst & $* *$ \\
\hline 23 & Berat Brangkasan Segar Total Pertanaman $60 \mathrm{Hst}$ & $* *$ \\
\hline 24 & Berat Brangkasan Segar Total Pertanaman 75 Hst & $* *$ \\
\hline 25 & Berat Brangkasan Segar Total Pertanaman 90 Hst & $* *$ \\
\hline 26 & Berat Kering Oven Total Pertanaman 30 Hst & $* *$ \\
\hline 27 & Berat Kering Oven Total Pertanaman 45 Hst & $* *$ \\
\hline 28 & Berat Kering Oven Total Pertanaman 60 Hst & $* *$ \\
\hline 29 & Berat Kering Oven Total Pertanaman 75 Hst & $* *$ \\
\hline 30 & Berat Kering Oven Total Pertanaman $90 \mathrm{Hst}$ & $* *$ \\
\hline
\end{tabular}
Keterangan :

Hst : Hari Setelah Tanam

Dari data diatas diketahui bahwa, secara morfologi bibit salak pondoh memiliki

ciri dalam proses pertumbuhannya, dimana pada umur 30,45, dan 60 Hst bibit salak pondoh lebih konsentrasi 
terhadap tinggi tanaman, luas daun dan panjang akar di bandingkan dengan menambah jumlah daun. Kondisi ini sesuai dengan yang di kemukakan oleh, Ridge (1991), yang menyatakan bahwa organ tanaman yang berperan dalam penyerapan unsur hara adalah akar sementara gas $\mathrm{O} 2$ dan $\mathrm{Co} 2$ diserap oleh daun. Dalam hal ini memperlebar luas daun lebih menguntungkan bagi tanaman tertentu dibandingkan dengan menambah jumlah daun.

Tabel 2 Pengaruh Pupuk Organik Kandang Ayam Terhadap Tinggi Tanam Jumlah Daun, Luas Daun, Panjang Akar, Berat Segar, dan Berat Kering Oven Tanaman Salak Pondoh Pada Setiap Umur Pengamatan

\begin{tabular}{|c|c|c|c|c|c|c|}
\hline \multirow{2}{*}{ Variabel } & \multirow{2}{*}{ Perlakuan } & \multicolumn{5}{|c|}{ Umur Pengamatan (HST) } \\
\hline & & 30 & 45 & 60 & 75 & 90 \\
\hline \multirow{5}{*}{ Tinggi Tanaman } & $\mathrm{POO}$ & $16,25 \mathrm{e}$ & $19,75 \mathrm{e}$ & $24,25 \mathrm{e}$ & $28,25 \mathrm{e}$ & $34,25 \mathrm{e}$ \\
\hline & PO1 & $17,50 \mathrm{~d}$ & $22,00 \mathrm{~d}$ & $25,75 \mathrm{~d}$ & $28,75 \mathrm{~d}$ & $34,75 \mathrm{~d}$ \\
\hline & $\mathrm{PO} 2$ & $19,50 \mathrm{c}$ & $23,50 \mathrm{c}$ & $27,25 \mathrm{c}$ & $29,75 \mathrm{c}$ & $35,75 \mathrm{c}$ \\
\hline & PO3 & $21,25 \mathrm{~b}$ & $24,25 \mathrm{~b}$ & $30,50 \mathrm{~b}$ & $30,75 \mathrm{~b}$ & $36,50 \mathrm{~b}$ \\
\hline & PO4 & $22,50 \mathrm{a}$ & $27,25 \mathrm{a}$ & $30,75 \mathrm{a}$ & $33,25 \mathrm{a}$ & $38,50 \mathrm{a}$ \\
\hline \multicolumn{2}{|c|}{ BNT $5 \%$} & 1,85 & 2,02 & 1,76 & 1,62 & 1,36 \\
\hline \multirow{5}{*}{ Jumlah Daun } & $\mathrm{POO}$ & $1,00 \mathrm{~b}$ & $1,00 \mathrm{c}$ & $1,00 \mathrm{c}$ & $1,25 \mathrm{e}$ & $1,75 \mathrm{e}$ \\
\hline & PO1 & $1,00 \mathrm{~b}$ & $1,00 \mathrm{c}$ & $1,00 \mathrm{c}$ & $1,50 \mathrm{~d}$ & $2,00 \mathrm{~d}$ \\
\hline & $\mathrm{PO} 2$ & $1,00 \mathrm{~b}$ & $1,00 \mathrm{c}$ & $1,00 \mathrm{c}$ & $1,75 \mathrm{c}$ & $2,50 \mathrm{c}$ \\
\hline & PO3 & $1,00 \mathrm{~b}$ & $1,25 \mathrm{~b}$ & $1,50 \mathrm{~b}$ & $2,00 \mathrm{~b}$ & $2,75 \mathrm{~b}$ \\
\hline & $\mathrm{PO} 4$ & $1,25 \mathrm{a}$ & $1,75 \mathrm{a}$ & $1,75 \mathrm{a}$ & $2,75 \mathrm{a}$ & $3,00 \mathrm{a}$ \\
\hline \multicolumn{2}{|c|}{ BNT $5 \%$} & 0,34 & 0,56 & 0,56 & 0,61 & 0,64 \\
\hline \multirow{5}{*}{ Luas Daun } & $\mathrm{PO} 0$ & $60,00 \mathrm{e}$ & $80,00 \mathrm{e}$ & $125,00 \mathrm{e}$ & $180,00 \mathrm{e}$ & $200,00 \mathrm{e}$ \\
\hline & PO1 & $65,00 \mathrm{~d}$ & $85,00 \mathrm{~d}$ & $135,00 \mathrm{~d}$ & $185,00 \mathrm{~d}$ & $210,00 \mathrm{~d}$ \\
\hline & $\mathrm{PO} 2$ & $100,00 \mathrm{c}$ & $115,00 \mathrm{c}$ & $165,00 \mathrm{c}$ & $210,00 \mathrm{c}$ & $235,00 \mathrm{c}$ \\
\hline & PO3 & $115,00 \mathrm{~b}$ & $130,00 \mathrm{~b}$ & $170,00 \mathrm{~b}$ & $215,00 \mathrm{~b}$ & $240,00 \mathrm{~b}$ \\
\hline & $\mathrm{PO} 4$ & $135,00 \mathrm{a}$ & $155,00 \mathrm{a}$ & $200,00 \mathrm{~d}$ & $235,00 \mathrm{a}$ & $265,00 \mathrm{a}$ \\
\hline \multicolumn{2}{|c|}{ BNT $5 \%$} & 18,01 & 16,64 & 24,68 & 19,29 & 23,70 \\
\hline \multirow{5}{*}{ Panjang Akar } & PO0 & $11,50 \mathrm{e}$ & $14,75 \mathrm{e}$ & $19,75 \mathrm{e}$ & $24,25 \mathrm{e}$ & $29,75 \mathrm{e}$ \\
\hline & PO1 & $12,00 \mathrm{~d}$ & $16,25 \mathrm{~d}$ & $21,75 \mathrm{~d}$ & $26,50 \mathrm{~d}$ & $32,50 \mathrm{~d}$ \\
\hline & $\mathrm{PO} 2$ & $12,75 \mathrm{c}$ & $17,50 \mathrm{c}$ & $22,50 \mathrm{c}$ & $26,75 \mathrm{c}$ & $33,00 \mathrm{c}$ \\
\hline & PO3 & $13,75 \mathrm{~b}$ & $19,50 \mathrm{~b}$ & $24,00 \mathrm{~b}$ & $30,25 \mathrm{~b}$ & $37,25 \mathrm{~b}$ \\
\hline & $\mathrm{PO} 4$ & $16,25 \mathrm{a}$ & $24,00 \mathrm{a}$ & $28,00 \mathrm{a}$ & $31,75 \mathrm{a}$ & $38,25 \mathrm{a}$ \\
\hline \multicolumn{2}{|c|}{ BNT $5 \%$} & 3,03 & 2,04 & 2,19 & 3,69 & 2,64 \\
\hline \multirow{5}{*}{ Berat Segar } & $\mathrm{PO} 0$ & $2,75 \mathrm{e}$ & $4,00 \mathrm{e}$ & $5,75 \mathrm{e}$ & $8,25 \mathrm{e}$ & $10,75 \mathrm{e}$ \\
\hline & PO1 & $3,25 \mathrm{~d}$ & $4,50 \mathrm{~d}$ & $6,25 \mathrm{~d}$ & $8,50 \mathrm{~d}$ & $13,00 \mathrm{~d}$ \\
\hline & $\mathrm{PO} 2$ & $3,50 \mathrm{c}$ & $5,75 \mathrm{c}$ & $7,75 \mathrm{c}$ & $11,50 \mathrm{c}$ & $14,50 \mathrm{c}$ \\
\hline & PO3 & $4,25 \mathrm{~b}$ & $6,75 b$ & $9,00 \mathrm{~b}$ & $13,50 \mathrm{~b}$ & $16,25 \mathrm{~b}$ \\
\hline & PO4 & $5,25 \mathrm{c}$ & $8,25 \mathrm{a}$ & $10,75 \mathrm{a}$ & $15,25 \mathrm{a}$ & $18,50 \mathrm{a}$ \\
\hline \multicolumn{2}{|c|}{ BNT $5 \%$} & 1,23 & 1,08 & 1,76 & 1,72 & 1,56 \\
\hline \multirow{6}{*}{$\begin{array}{l}\text { Berat } \\
\text { Oven }\end{array}$} & PO0 & $0,48 \mathrm{e}$ & $0,73 \mathrm{e}$ & $0,95 \mathrm{e}$ & $1,63 \mathrm{e}$ & $2,13 \mathrm{e}$ \\
\hline & PO1 & $0,55 \mathrm{~d}$ & $0,78 \mathrm{~d}$ & $1,15 \mathrm{~d}$ & $1,78 \mathrm{~d}$ & $2,38 \mathrm{~d}$ \\
\hline & $\mathrm{PO} 2$ & $0,68 \mathrm{c}$ & $0,95 \mathrm{c}$ & $1,28 \mathrm{c}$ & $2,05 \mathrm{c}$ & $2,93 \mathrm{c}$ \\
\hline & PO3 & $0,75 \mathrm{~b}$ & $1,03 \mathrm{~b}$ & $1,48 \mathrm{~b}$ & $2,40 \mathrm{~b}$ & $3,05 \mathrm{~b}$ \\
\hline & PO4 & $0,80 \mathrm{a}$ & $1,30 \mathrm{a}$ & $1,73 \mathrm{a}$ & $3,15 \mathrm{a}$ & $3,55 \mathrm{a}$ \\
\hline & & 0,18 & 0,13 & 0,22 & 0,20 & 0,21 \\
\hline
\end{tabular}

Keterangan : Angka-angka yang diikuti oleh huruf yang sama pada kolom yang sama berarti menunjukan pengaruh yang tidak berbeda nyata pada taraf uji BNT 5\%. 
Berdasarkan hasil analisis sidik ragam menunjukan bahwa penggunaan pupuk organik kandang ayam memberikan pengaruh yang sangat nyata terhadap variabel pertumbuhan tinggi tanaman, jumlah daun, luas daun, panjang akar, berat segar brangkasan, dan berat kering oven (Tabel 2).

Hasil analisis sidik ragam menunjukan bahwa penggunaan dosis pupuk organik kandang ayam yang berbeda memberikan pengaruh yang sangat nyata terhadap variabel pertumbuhan. Pengamatan yang ditunjukkan pada tabel 2 untuk masingmasing umur pengamatan terjadi perbedaan yang sangat nyata antara tanaman yang diberikan pupuk organik kandang ayam dan tidak diberikan pupuk organik kandang ayam.

Hasil analisis sidik ragam menunjukan bahwa penggunaan pupuk organik kandang ayam dari dosis 0 gram polibag $^{-1}\left(\mathrm{PO}_{0}\right) \quad \mathrm{ke}$ dosis 50 gram polibag $^{-1} \quad\left(\mathrm{PO}_{1}\right)$ terjadi peningkatan rataan tinggi tanaman sebesar 4,89\%, jumlah daun sebesar $12,50 \%$, luas daun sebesar 5,43\%, panjang akar sebesar $8,50 \%$, berat segar sebesar $12,70 \%$, dan berat kering oven sebesar $12,16 \%$; dari dosis 0 gram polibag ${ }^{-1}\left(\mathrm{PO}_{0}\right)$ ke dosis 100 gram polibag ${ }^{-1} \quad\left(\mathrm{PO}_{2}\right)$ terjadi peningkatan ratan tinggi tanaman sebesar 10,59, jumlah daun sebesar $20,83 \%$, luas daun sebesar 27,91\%, panjang akar 12,05\%, berat segar $36,51 \%$ dan berat kering oven sebesar $33,28 \%$; dari dosis 0 gram polibag ${ }^{-1} \mathrm{ke}$ dosis 150 gram polibag ${ }^{-1}\left(\mathrm{PO}_{3}\right)$ terjadi peningkatan rataan tinggi tanaman sebesar 17,11\%, jumlah daun sebesar $41,76 \%$, luas daun sebesar 34,88\%, panjang akar sebesar $24,75 \%$, berat segar sebesar $57,94 \%$, dan berat kering oven sebesar 47,13\%; dari dosis 0 gram polibag $^{-1}\left(\mathrm{PO}_{0}\right)$ ke dosis 200 gram polibag $^{-1} \quad\left(\mathrm{PO}_{4}\right)$ terjadi peningkatan rataan tinggi tanaman sebesar 24,03\%, jumlah daun sebesar $70,81 \%$, luas daun sebesar 53,49\%, panjang akar sebesar $38,25 \%$, berat segar sebesar $84,13 \%$ dan berat kering oven sebesar 77,87\%. Hasil menunjukkan semakin tinggi dosis pupuk organik kandang ayam yang diberikan akan mampu menyediakan kebutuhan unsur hara dalam tanah sehingga unsur hara yang tersedia cukup bagi tanaman. Pupuk organik kandang ayam telah diketahui dari berbagai penelitian memiliki unsur hara lengkap baik dari jenis unsur hara mikro maupun makro yang berfungsi untuk menyuburkan tanaman, memperbaiki struktur tanah dan meningkatkan 
aktivitas jasat renik tanah. Hasil diserap tumbuhan secara langsung, penelitian Ridwan Ahmad dkk (2017), sehingga relatif tidak perlu proses mengatakan bahwa pupuk organik dekomposisi terlebih dahulu. Dimana kandang ayam Perlakuan pupuk kandang fungsi $\mathrm{N}$ bagi tanaman diperlukan untuk ayam berpengaruh nyata terhadap pembentukan atau pertumbuhan bagian parameter pengamatan volume akar, bobot kering akar dan bobot kering tajuk pada bibit kopi robusta.. Kondisi yang sama diperlihatkan oleh penelitian Tarigan L, dkk (2014), dengan pemberian pupuk organik kandang ayam dapat berpengaruh nyata terhadap tinggitanaman (12 dan 14 MST), jumlah daun ( 8, 10 dan 12 MST), diameter batang, total luas daun, obot basah tajuk, bobot kering tajuk dan bobot basah akar pada bibit kakao.

Kondisi di atas, disebabkan karena pupuk organik kandang ayam memiliki kandungan seperti Nitrogen (N), Fosfor (P), kalium (K), kalsium (Ca), Magnesium (Mg), dan sulfur (S) dalam jumlah yang cukup sehingga mampu menyediakan kebutuhan unsur hara dalam tanah untuk pertumbuhan tanaman. Dimana kandungan unsur hara pupuk dari kotoran ayam diantaranya: $\mathrm{N}$ (5\%), P (0,81\%); K (0,4\%) dan air (55 $\%)$. Kandungan unsur hara N pada kotoran ayam relatif tinggi dibanding pupuk kandang jenis lain. Terlebih lagi, unsur $\mathrm{N}$ dalam kotoran ayam bisa vegetatif tanaman ( daun, batang dan akar), berperan penting dalam hal pembentukan hijau daun yang berguna sekali dalam proses fotosintesis, membentuk protein, lemak dan berbagai persenyawaan organik serta meningkatkan perkembangbiakan mikroorganisme di dalam tanah. Pemberian dosis yang tinggi, juga akan meningkatkan kandungan unsur hara bagi tanaman yang berperan dalam membantu pertumbuhan dan perkembangan tanaman, karena pupuk kandang ayam mengandung $\mathrm{N}$ dan air yang paling banyak dibutuhkan tanaman. (Sutono, 2002; Khair et al, 2013).

Perlakuan pupuk organik kandang ayam dengan dosis 200 gram polibag $^{-1}$ $\left(\mathrm{PO}_{4}\right)$ memberikan peningkatan peresentaze rataan total tinggi tanaman, jumlah daun, luas daun, panjang akar, berat segar, dan berat kering oven dibandingkan dengan perlakuan lainnya. Hal ini disebabkan karena semakin banyak dosis pupuk organik kandang ayam yang diaplikasikan maka akan semakin banyak unsur hara yang diserap 
oleh akar tanaman untuk mendukung proses pertumbuhan. Karena penggunaan pupuk organik kandang ayam yang semakin banyak dapat menyuburkan tanaman dan membuat tanah menjadi subur (Sutedjo, 2010).

Berdasarkan hasil analisis tersebut, dosis 100 gram polibag ${ }^{-1}\left(\mathrm{PO}_{2}\right)$ belum mampu memberikan pertumbuhan bibit salak pondoh yang optimal dibandingkan dengan dosis 200 gram polibag-1 $\left(\mathrm{PO}_{4}\right)$. Hal ini disebabkan kerena faktor lingkungan dan kondisi di tempat penelitian terjadi kesenjangan yang berkaitan dengan syarat tumbuh bibit salak pondoh sehingga belum mampu memberikan pertumbuhan bibit salak pondoh yang optimal. Tanah basah yang kaya bahan organik, gembur, dapat menyimpan air, tidak tergenang air dan mengandung unsur hara yang penting adalah tanah yang cocok digunakan dalam pembibitan salak pondoh, akan tetapi di lokasi penelitian jenis tanahnya adalah tanah lempung berpasir dan tergolong rendah dengan nilai $\mathrm{C}$ organik, $\mathrm{N}$, maupun $\mathrm{P}$ dan $\mathrm{K}$ tergolong sedang. Oleh sebab itu bibit salak pondoh yang diberikan dengan dosis 100 gram polibag $^{-1}$, masih belum mampu mencukupi kebutuhan bibit salak pondoh dalam menyerap unsur hara Nitrogen.
Hal tersebut diduga adanya proses kehilangan Nitrogen melalui penguapan karena panas dan meresap kedalam tanah akibat dari jenis tanahnya mengandung pasir sehingga unsur $\mathrm{N}$ yang digunakan untuk pertumbuhan berlangsung lebih sedikit dibandingkan dengan dosis 200 gram polibag $^{-1}$. Dosis 200 gram polibag $^{-1}$ akan mampu memberikan suplai unsur hara dan memperbaiki kondisi tanah di media tanam yang digunakan dalam membantu proses pembibitan salak pondoh sehingga kandungan unsur hara tanah dapat dipertahankan (Sutoyo et al, 2010).

Bibit salak pondoh tanpa pemberian pupuk organik kandang ayam $\left(\mathrm{PO}_{0}\right)$ memberikan penampilan variabel pertumbuhan yang paling rendah dibandingkan perlakuan lainnya. Hal ini disebabkan oleh kurangannya unsur hara yang diperoleh bibit salak pondoh dari perlakuan $\mathrm{P}_{0}$, sehingga berdampak pada penurunan pertumbuhan bibit salak pondoh (Ismail, 2013).

\section{SIMPULAN DAN SARAN}

Berdasarkan hasil penelitian dengan penggunaan Pupuk Organik Kandang Ayam terhadap bibit Salak Pondoh (salaca edulis Reinw) dapat disimpulkan bahwa : 
1. Hasil penelitian menunjukan bahwa pemberian pupuk organik kandang ayam memberikan pengaruh yang sangat nyata terhadap ratan total tinggi tanaman sebesar $14,15 \%$, jumlah daun bibit $^{-1}$ sebesar $36,46 \%$, luas daun bibit ${ }^{-1}$ sebesar $30,43 \%$, panjang akar sebesar $21,00 \%$, berat segar total $\tan ^{-1} 47,42 \%$, berat kering oven total $\tan ^{-1} 42,44 \%$.

2. Dosis optimum pupuk organik kandang ayam yang memberikan pertumbuhan bibit salak pondoh yang optimal adalah 200 gram polibag $^{-1}$.

Dosis pupuk organik kandang ayam yang dianjurkan untuk meningkatkan pertumbuhan bibit salak pondoh yang optimal adalah 200 gram polibag $^{-1}$.

\section{UCAPAN TERIMA KASIH}

Penelitian ini dapat dilaksanakan karena adanya beberapa pihak yang mendukung kami, untuk itu perkenankanlah kami menyampaikan ucapan terimakasih kepada : Ibu Dr. Sri Wahyuni, SP.,M.Si yang telah memberikan masukan, kritik dan saran kepada penulis Serta semua pihak yang telah membantu penelitian.

\section{DAFTAR PUSTAKA}

Anarsis. 2006. Agribisnis Komoditas Salak. Bumi Aksara. Jakarta.
Ahmad Ridwan Lubis, Lisa Mawarni, Rosita Sipayung, 2017. Respon Pertumbuhan Bibit Kopi Robusta (Coffea robusta L.) Terhadap Pemberian Pupuk Kandang Ayam dan Pupuk Organik Cair Jurnal Agroekoteknologi FP USU EISSN No. 23376597Vol.5.No.3, Juli 2017 (88): 692- 696

Alinajati, S.S., B. Mirshekari. 2011. Effect of phosphorus fertilization and seed bio fertilization on harvest index and phoshorus use efficiency of wheat cultivars. J Food, Agri \& Enviro 9(2): 388-397.

Gomez, K.A., Gomez, A.A. 2007. Prosedur Statistik Untuk Penelitian Pertanian. Jakarta. Universitas Indonesia Press.

Khair H.,Pasyaribu M.S.,Suprapto E. 2013. Respon Pertumbuhan dan Produksi Tanaman Jagung (Zea mays L.) Terhadap Pemberian Pupuk Kandang Ayam dan Pupuk Organik Cair Plus. Agrium.

Liperi Tarigan, Ferry Ezra Sitepu, Ratna Rosanty Lahay, 2014 Respon Pertumbuhan Bibit Kakao (Theobroma cacao L.) terhadap Pemberian Pupuk Kandang Ayam dan Pupuk Organik Cair. Jurnal Online Agroekoteknologi . ISSN No. 2337- 6597 Vol.2, No.4 : 1614 - 1626 , September 2014

Ismail Fahmi.2012 media tanam sebagai faktor eksternal Yang 
mempengaruhi pertumbuhan tanaman (PBT Ahli Pertama) Balai Besar Perbenihan dan Proteksi Tanaman Perkebunan Surabaya

Mayadewi, 2007. Pengaruh Jenis Pupuk Kandang danJarak Tanam terhadap Pertumbuhan Gulmadan Hasil Jagung Manis. Agritrop, 26 (4) : 153- 159.

Purnomo, H. 2001. Budidaya Salak Pondoh. Aneka Ilmu. Semarang. 70 hal.

Rachman IA, Djuniwati S, Idris K. 2008. Pengaruh bahan organik dan pupuk NPK terhadap serapan hara produksi jagung di inceptisol Ternate. Jenis Tanah dan Lingkungan.

Raihan, H.S. 2000. Pemupukan NPK dan ameliorasi lahan kering sulfat masam berdasarkan nilai uji tanah untuk tanaman jagung. J. Ilmu pertanian 9 (1): 20-28

Rahayu R.K. 2012. Pengaruh Dosis Kotoran Ayam Terhadap Pertumbuhan Bibit Dua Klon
Kakao (Theobroma cacao L.). Fakultas Pertanian-Universitas Jember. Jember

Ridge, I. 1991. Plant Physiology. Hodder \& Stoughton : Open University.

Subroto. 2009. Kesuburan dan Pemupukan Tanah Pertanian. Bandung: Pustaka Buana.

Sutedjo, M.M. 2010. Pupuk dan Cara Pemupukan. Rineka Cipta, Jakarta.

Widuri, Hesti., Mawardi, Dedi., 2013. Komponen Gizi dan Bahan Makanan untuk Kesehatan, Yogyakarta: Gosyen Publishing.

Widowati L.R., Sri Widati U., Jaenudin W., Hartatik. 2005. Pengaruh Kompos Pupuk Organik yang Diperkaya dengan Bahan Mineral dan Pupuk Hayati terhadap Sifat-sifat Tanah, Serapan Hara dan Produksi Sayuran Organik. Laporan Proyek Penelitian Program Pengembangan Agribisnis, Balai Penelitian Tanah, TA 2005 (Tidak dipublikasikan). 